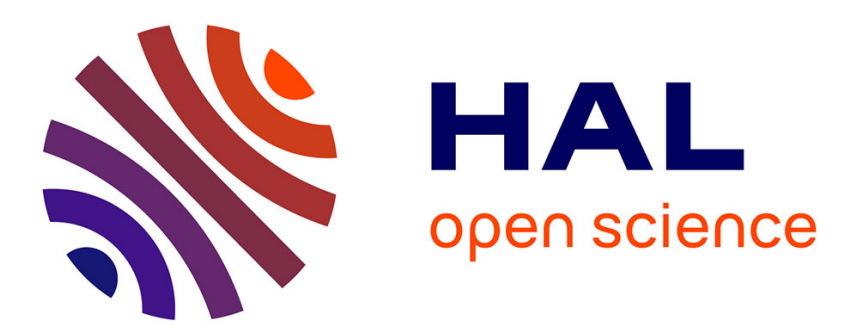

\title{
Fuzzy jobs in local partnerships : case studies of urban and rural regeneration in France and England
}

Gilles Jeannot, Barry Goodchild

\section{To cite this version:}

Gilles Jeannot, Barry Goodchild. Fuzzy jobs in local partnerships : case studies of urban and rural regeneration in France and England. Public Administration, 2011, 89 (3), pp.1110-1127. 10.1111/j.1467-9299.2011.01920.x . hal-00659630

\section{HAL Id: hal-00659630 \\ https://hal-enpc.archives-ouvertes.fr/hal-00659630}

Submitted on 4 Feb 2016

HAL is a multi-disciplinary open access archive for the deposit and dissemination of scientific research documents, whether they are published or not. The documents may come from teaching and research institutions in France or abroad, or from public or private research centers.
L'archive ouverte pluridisciplinaire HAL, est destinée au dépôt et à la diffusion de documents scientifiques de niveau recherche, publiés ou non, émanant des établissements d'enseignement et de recherche français ou étrangers, des laboratoires publics ou privés. 
FUZZY JOBS IN LOCAL PARTNERSHIPS: CASE STUDIES OF URBAN AND RURAL

REGENERATION IN FRANCE AND ENGLAND

Jeannot Gilles, Goodchild Barry

Pour citer : Jeannot Gilles, Goodchild Barry (2011), Fuzzy jobs in local partnerships: case studies of urban and rural regeneration in France and England, Public Administration, Wiley, 89 (3), pp. 1110-1127.

\section{Summary}

By means of an Anglo-French comparison, this article shows the existence of certain atypical forms of public sector work that are associated with internal and external coordination, particularly in the context of locality based partnerships. In the case of rural and urban development in France in the 1980s, such atypical work involved organizations that were on the fringe of local authorities, a job description that allowed for considerable autonomy and, finally, employment conditions that were often insecure. These are the essential components of 'fuzzy' jobs. Similar atypical characteristics can also be found elsewhere and in particular in contemporary practice for urban regeneration in England. Through a comparison of diverse situations, the article explores various factors that influence these forms of employment. The analysis reveals the heavy impact of the mechanisms for allocating public funds, as well as the difficulties in dealing with certain objectives in public policy. 


\section{INTRODUCTION}

This article explores the influence of institutional and organizational variations on the work practices of public officials fulfilling a transversal or boundary spanning role in the pursuit of joined up government in urban and rural areas. Boundary spanning has been an implicit or explicit aspect of many specific studies of cross-cutting, partnership working in France and England. This particular study gives these studies an international, comparative dimension, determining the extent to which shared features can be observed in two countries with very different systems of local government.

In addition, in doing all this, the aim is to reanalyse the characteristics of boundary spanning to show that, in certain circumstances, this can be regarded as an example of a distinct category of occupation - a 'fuzzy job' (Jeannot 2005a, b). This latter may be defined as a job that has the following characteristics:

1. an ambiguous position in the organization (multiple hierarchical accountability, duplication of other roles);

2. a very general job description, with tasks defined in relation to general policy prescriptions (sustainable development, empowerment and so on) and in a way that leaves considerable autonomy for everyday management and innovation; and finally

3. a more precarious employment contract than the average public sector officer.

The account looks at several dimensions of boundary spanning and by extension of a fuzzy job: the position of the official in the organization, the scope of the work and the conditions of employment. It starts with a review of the literature, first the literature dealing with the organization of urban policy in Britain and France and then broader, mostly AngloAmerican studies of professionalism and organizations. It goes on to report and analyse a series 
of case studies. Finally, in a discussion section, it suggests hypotheses for the emergence of fuzzy jobs as a specific, albeit unusual work role.

\section{FUZZY JOBS IN CONTEXT}

The modalities of boundary spanning have been discussed in various contexts, but mostly in the context of co-ordinated public policy initiatives. In Britain, the policies for 'joined-up government' of the Labour government elected in 1997 represent the best known example. The history of joined up government is longer than this, however. Coordinated forms of intervention appeared in the 1970s in Britain before being overshadowed by other practices in the 1980s and finally re-appearing, as in other countries (Ling 2002), as a reaction to the narrow, sectoral emphasis of new public management. The core of these coordinated initiatives was in urban policy and urban regeneration and the management of so-called 'wicked problems' (Rittel and Webber 1973; Harrison 2000) that implicate different established organizations. Through partnerships (Lowndes and Skelcher 1998) or networks, coordinated urban policies bring together, in the first instance, public bodies (Sullivan and Skelcher 2002) around such topics as crime prevention or economic development, around target groups such as young people, or around other specific local interventions. Coordination also extends to other organized groups within civil society (the voluntary sector) and the business community and then to the whole population through empowerment and consultation exercises.

In France, coordinated urban policies appeared independently in the early 1980s, albeit on the basis of earlier smaller scale initiatives and also alongside similar initiatives for rural development. The French national urban policy - la politique de la ville is organized around target territories selected according to socio-economic criteria. The policy focussed initially on the transformation of the built environment, on empowerment and on education; it has 
gradually widened to cover the fields of crime, employment and health. From the outset, it has sought to promote innovation, going outside conventional administrative frameworks and is therefore, by definition, based on partnership working. Later, similar cross-cutting approaches were adopted in France in public health with initiatives seeking to open hospitals up to their surrounding communities and in crime prevention policies, through the establishment of local coordinating committees (Douillet and De Maillard 2008). Co-ordinated forms of intervention have emerged, moreover, even if professional groups maintained a degree of distance from the various partnership procedures (Thoenig 1994).

Boundary spanning, collaboration and the role of the chef de projet

In pursuing these initiatives, the effectiveness of coordination does not just spring from the juxtaposition of organizations but from the work of networking or 'reticulist' practitioners (Friend et al. 1974) who are able to reach beyond the boundaries of the different public organizations. In this context, Bardach (1998) has put forward the idea that the capacity for interagency collaboration depends on practitioners employed for this specific purpose. Likewise, Williams (2002) has argued so-called 'boundary spanners' should constitute a compulsory checkpoint of organizational analysis (2002, p. 106):

I argue that the fixation at the organizational and interorganizational domain levels understates and neglects the pivotal contribution of individual actors in collaborative process. (...) The effectiveness and success of interorganizational ventures rests equally with the people involved in the process and their ability to apply collaborative skills and mind sets to the resolution or amelioration of complex problems. $\langle/$ ext $>$ 
Williams then highlights the issue of the skills of boundary spanners as a key issue in the implementation of cross-cutting policies- a theme that, following the analysis of the Egan report (ODPM 2004) in particular, has become a preoccupation in studies of urban policy and urban regeneration in Britain (Newman 2001; Bailey 2005; Kagan 2007). The questions of skills apart, the work practices and roles of boundary spanners have not been extensively studied in the UK. This neglect emerges clearly from reviews of 'joined up government' (Ling 2002; Pollitt 2003; Bogdanor 2005). Ling (2002) mentions the works by Clarke and Stewart (1997) which combine 'wicked issues' and boundary spanning but again reduces the issue of human resources to one of 'skills and learning'.

In France, in contrast, the occupational implications have drawn more attention. Research has focussed on the apparently curious figure of the chef de projet (the 'project director' or 'project manager') as established in the early 1980s in the first period of the politique de la ville (Blanc and Sipp 2000; Brevan and Picard 2000). The chef de projet is a single individual, whose salary is financed jointly by the state and the local authority and whose role is to call the different partners to account.

The resulting studies enable the identification of a series of characteristics of this particular role. The first characteristic, and one that led to debate beyond specialized circles, concerns the ambiguous organizational accountability of practitioners who work simultaneously for the state and for local authorities. Bourdieu (1991) commented on this aspect by drawing upon the example of a young employee who, originating from the very structured occupational circle of the social housing sector, expressed a sense of helplessness of working in a role without any clear lines of accountability. Donzelot and Estèbe (1994) responded that the apparent lack of accountability was not an indication of failure but the mark of a new style of public intervention, that of the enabling state.

The second characteristic concerns the working practices of the chef de projet and, in 
particular, their surprising degree of autonomy and creativity. A sizeable portion of the practices widespread today were invented by chefs de projet and spread through their occupational networks. A related theme is their capacity to intervene in spheres of action that are usually separate. In the same week, they may organize a consultation meeting for residents, intervene with a ministerial committee to defend a specific type of initiative or coordinate the interventions of the local authority with those of the decentralized offices of the state (Profession banlieue 1993, 1999; Behar and Estèbe 1996).

The third series of characteristics is concerned with the individuals undertaking relevant work. Ion (1996) noted how social workers, who could have been expected to occupy these new jobs, had been reluctant to do so. They had stepped aside in favour of those with experience in running local community centres or to activists from the trade unions or second generation immigration associations (Peraldi 1996).

The debate about the chef de projet overlaps a consideration of the factors that have influenced the emergence of what has been called, for want of a better expression, the 'new urban professions'. Three positions have been apparent. First, a macro-approach has linked their emergence to a crisis in traditional social work (Donzelot and Roman 1998; Cousin 1996). A second series of studies has emphasized the changing relationship between local and central government and, the emergence of 'government by contract' (Gaudin 1999). Finally, a third series of studies has linked the new forms of work to the cross-cutting character of urban problems (Duran and Thoenig 1996). The experience of the politique de la ville shows, in other words, that boundary crossing can become an unusual occupational category rather than a mere passing work role. 
Professions and organizations

The twin concepts of the 'new urban professions' and by extension of 'fuzzy jobs' derive from French research traditions. These traditions, nevertheless, draw on pragmatic, interactionist perspectives that are shared with English-speaking sociology. It is, as a result, possible to find parallel interpretations in the Anglo-American literature, mostly in accounts of 'semiprofessions', to use the language of Etzioni (1969), such as teachers, nurses, social workers and housing managers. where the process of professionalization is incomplete (Wilensky 1964).

In comparison with high status professions (such as doctors, lawyers and architects), incomplete professionalization sometimes involves uncertain work boundaries. For example, in a case study of social work in the US, Abbott (1995) suggested that work roles are only partly determined by competition between professions. Social work was also about 'bringing all professional forces together' for the benefit of the client. Likewise, in a study of housing management in Britain, Casey and Allen (2004) noted that 'going beyond the boundary, is a common theme in the professional's definition of good practice. Housing management lacks clearly defined technical skills. In this context, the idea of professionalization as a collective project as conceived by Larson (1977) and led by a national organization is largely irrelevant. Instead, professionalization is best conceived as a 'personal project of the self', undertaken by individuals. The result is a definition of profession as a group whose identity is based on a shared understanding of problems and who attempt to do their best for their employer and their clients.

At the crossroad between professions and organizations, Strauss et al. $(1963,1985)$ have, in particular, advanced the idea of a 'negotiated order' as essential to effective organizational working. A negotiated order, though patterned and contingent on structural factors, involves a permanent process of adjustment in the working arrangements of an organization. As initially elaborated, the negotiated order referred to work in the setting of hospitals. However, it always 
had a potentially wider relevance (Day and Day 1977). Strauss (1988), for example, has explored the issues in project work, showing how this invariably involves contingency planning and sometimes has to cope with disruptions to work flow. Without always using the same language, the sociology of organizations has also drawn attention to other factors that require adjustment and negotiations - duplication and overlap in organizational arrangements (Landau 1969), ambiguities in the definition of roles (Rizzo et al. 1970) and ends (March and Olsen 1976; Chun and Rainey 2005). Finally, Lerner and Wanat (1983), in an article entitled 'fuzzyness and bureaucracy' point to the way in which vague policy instructions may result in a mismatch between the initial intent and outcomes.

A study of 'fuzzy jobs in local partnerships' may, in other words, be related to long established lines of research that, in general terms, have shown the uncertainties of professional work and organizational structures. There are some differences, however. The concept of a negotiated order refers to the limitation of bureaucratic regulations within an organization. Inter-organizational negotiation involves looser arrangements in which the task of the researcher is to define the patterning of external forces (Strauss 1982, p. 358). In addition, unlike the type of fuzzy mandates proposed by Lerner and Wanat (1983), the focus is not on some unintended mismatch that is best avoided. It is about a permanent situation that is inherent in the type of policy initiative. 


\section{METHODOLOGY AND CASE STUDIES}

The concept of a fuzzy job draws, in addition, on another aspect of interactionist sociology, that of research method and, in particular, on the broad principles of grounded theory, as outlined by Glaser and Strauss (1967) and others. The research starts with observations of rural development in different localities in France.

A distinctive feature of grounded theory is that hypotheses are generated and refined as the research proceeds. It is also context specific in the sense that it is based on the specific characteristics of each case study. Despite the grounding in specifics, however, grounded theory seeks to generalize through specifying hypotheses for additional case studies (Mjøset 2005). To this extent, the methodology allows the interpretation of fuzzy jobs in area based development and management in France and England. Coordinated urban policy initiatives exist in most countries of western and northern Europe (Andersen and van Kempen 2003; Jacquier 2005). It is possible therefore that a similar interpretation might be applied to other countries. At present, however, any such generalization could only take the form of further hypotheses. The generalization of fuzzy jobs to partnership work in other forms of public policy, outside the field of area management, raises similar issues.

The research starts with observations of rural development in different localities in France. These observations have in turn generated hypotheses that have been applied to the implementation of urban policy in France and England. Taken together, the three case studies allow a comparison of different spheres of intervention (urban and rural) and, in the case of neighbourhood management, a varied French and English context.

The first research was conducted in 2003. It is based on interviews with all the development officers in the Franche-Comté region in France $(\mathrm{N}=95)$ and with other relevant actors $(\mathrm{N}=15)$. The officers were interviewed about their work and employment conditions 
both at the time and over their previous professional career.

The second research was conducted in 2008. It concerned two sites in England, at Sheffield and Kirklees $(\mathrm{N}=20)$ completed by a focus group with urban regeneration professionals undertaking part-time study $(\mathrm{N}=12)$. This focus group centred on the issue of career progress. In France, the study concerned with four sites - Rennes, Périgueux and its agglomeration and two areas in the Paris suburbs, Le Blanc Ménil and Villetaneuse $(\mathrm{N}=35)$. The interviews revolved around the organizational framework and working practices of the officers and their previous career history. The work of neighbourhood managers was a particular theme in the different sites.

To ensure consistency of treatment and in translation, the French researcher took part in all the interviews organized in England and an English researcher took part in the interviews organized in Rennes. Inasmuch as the object of the article is to discuss the similarities and the dissimilarities in these situations, the following account only presents the most salient features of the relations between the institutional forms and the occupational positions of these officers.

Case study: rural development in France

Policies for rural development started in France at the beginning of the 1970s with the implementation, by the local services of the state, of plans for rural management. These plans were the rural counterpart of the large scale master plans designed for urban areas and were associated with a production oriented farming policy. The context was one of a high level of centralization and a fragmented pattern of local government where literally thousands of small rural municipalities (communes) depended on the offices of the state for expertise and finance. The implementation of the approach saw however a departure from the initial aim of infrastructure provision. Instead, the policies became concerned with integrated economic and social development projects and with projects that might lay down the foundations for 
coordinated action between the rural municipalities.

The historical reconstruction of events, as reflected in the narratives of local officers in Franche-Comté, tends to highlight the influence of professionals in securing the relevant policy innovations. The professional engineers in charge of implementation took the new plans seriously and in a differentiated manner. In one of the departments in particular, Haute Saône, the head of the service hired officers on long-term contracts in order to implement these plans. Individuals with high levels of education, such as agricultural engineers and geographers, applied for the posts. Some were recruited to local services of the state, others were recruited to chambers of agriculture, professional bodies that offered consulting services in the farming world.

The contract officers then organized a series of meetings in all the villages, identified the most motivated inhabitants and encouraged their involvement in thematic working parties. These working parties, independent of the local mayors, in turn identified the main elements of subsequent stages of policies for rural development (federation of economic actors in agriculture and tourism, services to the population, legitimating an intervention on larger territories, designated as 'pays'). These elements were repeated and formalized in 1975 in a new procedure for a so-called 'country contract' (contrat de pays). Officers with a highly protected work status initiated the said policy. They handed it over for implementation to contract officers whose autonomy would enable them to work out the detailed modalities. All of them worked for relatively stable organizations, the state services and the chambers of agriculture. Moreover, the contract officers thought that they possessed a protected work status until they encountered the labour market again as result of the decentralization initiatives of 1983.

Decentralization thoroughly transformed the institutional and professional landscape of rural France. The communes were given full responsibility for the management of a range of 
local services and acquired 'global' operating budgets. But action at supra-communal scale involved subsidies granted by the state and other local authorities such as the Département and the Région and, at a later stage the Europe Union. To access these resources in the absence of inter-communal administrative structures, a similar pattern of relationships emerged in several areas of the region, that of a partnership between an entrepreneurial elected official and a development officer. The former, the elected official, wished to step into the still unchartered territory of inter-communal action in the hope that this would be justified at a later stage of a political career through higher level appointments (President of the Département, member of the national senate). The latter, the development officer had simultaneously to respond to the funding priorities and opportunities of different sponsors and legitimize their leadership of a team of local development actors. The elected officer and the technical officers shared a degree of autonomy of action and their roles were partially interchangeable. The organizational forms varied from case to case. They included local development associations, development associations linked to an inter-communal public establishment, or the use of long-term contract with research consultants. Whatever the detailed organizational form, the position of the development officers had become precarious. They had to finance their jobs by drawing a portion of the funds for which they prepared an application. The organization, for its own part, only lasted for the duration of the funding programme. The precarious character of the work contract in turn did not make the positions particularly attractive to job applicants. The positions became filled by people with lower education levels and, compared to their predecessors, sometimes with a more chaotic professional career.

A law introduced in 1999 on inter-communal structures produced a second abrupt break. The law provided significant sources of finance to promote the integration of the communes into inter-communal establishments. Financial incentives encouraged the rapid spread of these new types of organization to which the municipalities delegated a proportion of their 
administrative functions. The possibility of creating local groupings of communes- again called 'pays' (literally 'countries, with all the shades of meaning implicit in this term) - completed the institutional offer. The pays were, and remain, in charge of local development and were based initially on territories that corresponded to several inter-communal bodies established in 1995 and strengthened in 2000. In some cases the inter-communal organization emerged as a successor to pre-existing associations. In such a case the development officer became the administrative executive and was exposed to a tension between the ideals of development and the routine practice of management. If no development officer had previously been in post, one would be recruited, but did not occupy an executive role. In such cases, liaison with the local population and local companies tended to become marginalized. In the case of the pays, the senior development officers were responsible for the service and continued their activities within an institutional framework which remained largely unchanged from before. Newcomers to the post may have felt slightly lost in an entity with no clear mission and that appeared a little unreal.

This case study of rural development officers provides an initial indication of the preconditions for the emergence of a fuzzy job. In the early stages of policy innovation, the distinctive character of the work is directly related to the emergence of a new form of public intervention that is, in turn, based on the public recognition of a distinct type of problem (Duran and Thoenig 1996) and a desire to mobilize the local population in a process that acquires the name of 'development'. In the absence of institutional change, the response in some local districts is to create a new post whose job description and contract allows a large degree of professional autonomy. As a result, the autonomy and subsequent creativity of staff appear as a response to the specific character of the task.

Subsequent events show the weight of institutional conditions on the employment status of the rural development officers. At first relatively protected, they had to find funds for their 
work when they lost their dependence on the administrative and other services of the state. In the context of a sudden expansion of contractual policies (Gaudin 1999), rural development became tied to the ambitions of local politicians who sought to access grants for projects beyond the conventional boundaries of local government. Later, the institutionalization of intercommunal working led to a partial normalization of conditions, that is to say a partial standardization of roles, working methods and employment conditions. A similar process of partial normalization is also apparent in the contemporary situation of urban policy in France.

Case study: implementing la politique de ville in four localities in France From the time of the 'heroic period' of the early 1980s onwards, urban policy in France has been prone to periods of reflection, with an accumulation of measures and of repetitive initiatives rather than the clear cut breaks characteristic of rural development (Le Galès and Mawson 1994; Hall and Hickman 2002). The scope of intervention has, nevertheless, grown progressively to cover all public services related to local everyday life. The level of intervention has also switched from the neighbourhood to the commune and then to inter-communal organizations. At different times, policies have sought either to concentrate resources on a few targeted sites or to spread resources over a wider area.

As regards local organization and practitioners, the usual analysis is of a gradual 'municipalization', that is to say a gradual absorption into the structures of local government (De Maillard 2004). Municipalization has been associated with a distinct division of labour. The function of liaison with the local population has expanded, with the appointment of specialist officers under the control of chefs de projet or with the recruitment of part-time staff originating from such posts as neighbourhood wardens or educational liaison officers. There has also been a tendency towards the routinization of part of this work. For example, collaboration between the municipal services and social housing agencies, in relation to what is 
now called 'neighbourhood management' (the everyday management of public spaces, green spaces and refuse collection) originated as a pragmatic invention by the first chefs de projet, but now follows established procedures that specify and coordinate the role of all the institutional actors.

The case studies confirm the process of municipalization but also show areas of organizational ambiguity. The municipality of Rennes chose to organize its intervention around six neighbourhood teams without, however, completely clarifying lines of responsibility. The technical services department in charge of implementation receives requests from the neighbourhood teams but action proceeds on a non-hierarchical basis with priorities being set by other service departments (street cleaning, housing and so on). The commune of Blanc Ménil has also sought to integrate urban policy into its current management processes and has recorded the relevant posts within its organizational chart. Yet recruitment was undertaken directly by a local voluntary group that was responsible for community development. Similarly in the case of Villetaneuse, the head of the urban policy service has demanded close integration into the municipal administration but the creation of a specific, dedicated department is on hold. In a small town like Périgueux, urban policy is integrated by default, the subject not being important enough to justify a full-time appointment.

In addition, a requirement to conduct urban policy at an inter-communal level has failed to clarify the situation, not least because each arrangement between a commune and an intercommunal body is unique. In the case of Rennes, only one priority neighbourhood is situated in a commune other than Rennes. The municipal services of Rennes have retained the key human resources necessary to implement the policy, that is tens of staff. The inter-communal body is theoretically responsible for urban policy but only possesses the framework for implementation, not the means. In the case of Périgueux the complication arises from the fact that the boundaries of the inter-communal body exclude the commune with the most severe social difficulties. 
Consequently, an additional ad hoc coordinating body has had to be created, with uncertain legitimacy. Finally, in the case of Villetaneuse, the inter-communal body is responsible for community development but the state subsidies have been directly allocated to the commune.

The continuing interventions of the state also work against local coordination. The state has in fact never stopped interfering in the implementation of urban policy (Le Galès 1995; Chevalier 1996). The creation of the Agence Nationale de Rénovation Urbaine (l'ANRU - the national agency for urban renewal), intended to support demolition and reconstruction, is the most recent example (Epstein 2005). In Rennes, the director of housing has become the local contact person for l'ANRU. However, to conform to a guideline of the agency, the officer in charge of applications is accountable to the urban policy service. In Villetaneuse, the intercommunal body has complete control and has financed a team to undertake the projects of l'ANRU. The complications arise in implementation. The responsible officers depend on the inter-communal body but have daily working relations with the commune.

These organizational ambiguities generate many positions that are ill-defined or riddled with contradictions. The effect on professional careers is, however, not as marked as in the case of the rural development, due to the gradual character of the policy transformations and due, in addition, to a lack of occupational mobility. The most sought-after posts, that is to say senior posts within the urban policy service, generally with a contractual status under French employment law, co-exist with fonctionnaires (professional officers with a protected legal status) who consider this type of intervention as just one aspect of their work. In Rennes, for example, a department for social interventions where the person in charge made their career in urban policy coexists alongside the urban renewal operations that are entrusted to a fonctionnaire integrated to the housing department. At a lower level in Rennes the neighbourhood teams also comprise a mixture of urban policy practitioners and fonctionnaires. For less sought-after posts, in particular in smaller towns, another type of division can be seen 
between new recruits with specialized training and who consider this as a professional specialism rather than a personal calling and individuals who have ended up in these little sought-after posts for want of a better offer.

As regards working practices, it is possible to identify both positive and negative forms of routinization. On one hand, certain initial forms of intervention, invented in the first era of urban policy, have acquired stable procedures. This is particularly the case in relation to activities dealing with the maintenance of public spaces, safety and crime prevention and consultation with local residents. On the other hand, certain forums for partnership and confrontation have lost their previous importance and the relevant facilitators diverted to bureaucratic tasks such as monitoring subsidy applications. This latter effect is, nevertheless, limited when the facilitators have prior experience. A portion of the more senior chefs de projet continue to work across the hierarchy.

Municipalization is the latest stage in the evolution of urban policy, but is strongly disrupted by external interventions, notably the requirement to pursue the policy at an intercommunal level and the return of the state in a very direct way by the means of l'ANRU. How should one see this recurrent failure to pursue a consistent line? Is it the result of contradictory, stop and go policies or of an incoherent institutional framework or as another indication of the difficulties tied to the promotion and coordination of development, similar to the difficulties that have also arisen in rural areas. A detour to another country may, in this context, be illuminating.

Case study: neighbourhood management in two English towns Are these types of job forms specific to the French situation? A look at the various practices in the field of neighbourhood management and related community-based exercises in two English towns leads to a nuanced answer. Neighbourhood management is well-suited to a study of 
fuzzy jobs. According to context, neighbourhood management can cover the management of neighbourhood centres, consultation with residents, the management of external spaces and the management of housing blocks. In addition, it is subject to varied local authority interpretation as to the size of management areas, the level of staffing that is considered appropriate, the range of policy fields that should be included and the selection of targeted areas. As in France, neighbourhood management is generally pursued as a means of managing deprived areas and as an aspect of broader policies to tackle urban deprivation.

If local authority structures are generally simpler than in France, the numerous relevant national funding programmes fragment intervention and have also led to the creation of autonomous local employer entities. Such is the case, for instance, of a body created in Sheffield for the implementation of the New Deal for Communities programme. The initiatives of the body receiving NDC funds offer the full range of initiatives developed in France (community development, including the rehabilitation of a community hall, education, safety, health and the environment) under the politique de la ville. Initiatives are organized by a team of practitioners: 20 people at the time of the interviews in 2008. In relation to their employment status, the officers possess permanent contracts. Since, however, the organization is to be dissolved in 2011, this corresponds to a fixed-duration job. The projects have also generated jobs outside the sphere of the official body. These are concerned with the follow-up of projects or support jobs for posts of mediation, teaching assistants or neighbourhood warden. The duration of these posts also depends on the availability of national funding.

The fragmentation of programmes extends to the voluntary sector. Such is the case for instance in Sheffield of a large Development Trust, created in 1997 on the basis of pre-existing local organizations, to manage the influx of monies from the Single Regeneration Budget (SRB). In comparison to the NDC agency, the Development Trust is relatively autonomous. However, its activities have been largely defined by the availability of public funds and these 
were heavily cut back with the end of the SRB and then of European-funded programmes. The organization has also had to manage a drop in staff numbers in the wake of dwindling public funds.

To avoid an over concentration of effort on specific areas, local authorities can also attempt to integrate national neighbourhood regeneration programmes into their mainstream services in a way that parallels the process of municipalization in France. For example, Kirklees District Council created in 2001 a Neighbourhood Management programme supported by national Neighbourhood Renewal funds, managed and monitored by a team of six people. Once the funding came to a close in 2008 , the officers had to apply for other posts within the local authority.

In Sheffield, the same desire to internalize and integrate the resources of a national programme is apparent in the case of the Housing Market Renewal (HMR) programme, intended to stimulate the local housing market. The team implementing this programme is included within the organizational structure of the local authority. It is part of the "housing strategy' sub-department within the 'Neighbourhood and Community care' department following the Local Strategic Partnership. The implementation of the HMR programme was at the time of the study in 2008 undertaken by three teams of some 15 people. The officers in charge of the project are financed by the HMR, but they possess permanent employment contracts as employees of the local authority. Their contract is not tied to the duration of the HMR programme. One of the main arguments for this was to attract good quality officers and to maintain their commitment towards the end of the contract.

At the same time, the level of integration varies according to the field of intervention. For example, the professional planners responsible for master planning remain in the relevant planning services department of the local authority; those responsible for managing the modernization of the housing stock are inserted into local housing teams, while the officers in 
charge of neighbourhood management have a more ambiguous role. One of those interviewed was connected simultaneously to the regeneration service, to the participative democracy schemes with district elected officials and to an informal collective body dedicated to neighbourhood management. As in the French case, this ambiguous accountability gives individual workers a degree of discretion to act independently.

A district-wide partnership, the Local Strategic Partnership (LSP) offers another means of promoting administrative integration, covering other public sector services (the health service, the police), the voluntary sector and local businesses as well as local authority services (Stewart and Howard 2004). The establishment of LSPs was initially tied to the national Neighbourhood Renewal Fund. Local authorities had to establish a LSP if they wished to gain access to the relevant funds. They have subsequently become the sign of a local commitment to partnerships of all types and provide a means, at least in theory, of defining strategic aims for a district.

The management of the LSP involves different organizational arrangements in relation to its different components. Some officers conduct coordinating actions on top of their other responsibilities for the local authority. Others are strongly in favour of the partnership and find it difficult to have real autonomy with respect to a municipal administration that controls most of the means available. Such organizational ambiguity parallels the pattern in France, both in urban areas and rural pays.

The English case studies have not permitted systematic follow-up work of the careers of boundary spanners. However, discussions with officers involved in resident consultation and in the voluntary sector and through the focus group of regeneration practitioners revealed a particularly unpredictable professional career pattern for a sizeable proportion of practitioners. Typical patterns might involve the accumulation of specific work commitments over several years, combined with occasional reorientations from one service field to another or switching from the voluntary sector to local government administration or vice versa (Lewis 2008). 
Policies for neighbourhood management in England have not led to the creation of fuzzy jobs exactly comparable to the chefs de projet. Nevertheless, certain common characteristics are apparent: organizational ambiguity in the official partnerships and in the associated local authority organizations; fixed-term jobs in the satellite organisms (voluntary sector or suitable programme bodies) and, in the case of officers working for municipal organizations, redundancy or redeployment where the post depends on national financing; finally a combination of relative autonomy and marginalization of practitioners who undertake consultation and liaison with the local population.

In England, it has proved just as difficult as in France to stabilize the means of policy intervention and for similar reasons. The experience in Sheffield and Kirklees point, in particular, to the potentially fragmenting effects of the funding mechanisms, especially the existence of separately funded, national projects and programmes. Faced with the destabilizing impact of these funding arrangements, neither the traditional bureaucratic form of administration nor the establishment of partnerships were able to resolve all the organizational ambiguities.

\section{DISCUSSION}

Taking all these examples together, the first and most obvious point is the way that 'fuzzy jobs' appear in all the various contexts. The main characteristics of fuzzy jobs (organizational ambiguity, imprecise job description and job insecurity) appear amongst those promoting economic development in rural areas as well as those promoting community development in deprived suburban and inner city areas. Alike, they appear in countries (France and England) with different patterns of local/central relations and different traditions of public service. The full expression of a fuzzy job, covering the three dimensions mentioned in the initial definition 
(organization, employment status, definition of the activity) is, nevertheless, fully accomplished only for the chefs de projet in the early period of French urban policy and for rural development officers in the period immediately prior to decentralization. Otherwise, conformity to the concept of fuzzy jobs is a matter of degree.

The condition for the emergence of fuzzy jobs

The variation in contexts suggests certain hypotheses regarding the conditions in which fuzzy jobs might emerge. The characteristics of fuzzy jobs in the three case studies is summarized in table 1 and analysed thereafter.

The first condition, revealed in particular when considering rural development in France and urban regeneration in England, concerns the circulation of public monies. The modalities of public finance provide an external patterning factor, to use the language of Strauss (1982), that helps determine the division of labour between different organizations or, in the case of local authorities, between different departments. Equally, the use of subsidies from higher government levels has a destabilizing effect on local organizations in all the case study areas, though the scale of the impact varies.

The most obvious example of destabilization is in England with the installation of ad hoc, independent organizations as the New Deal for Communities programme (row F of table 1). A similar destabilizing effect was apparent in France amongst the rural development associations in the 1980s which, after decentralization, entirely depended on subsidies (row B). The reemergence of direct interventions in urban regeneration in France (row E), as represented by l'ANRU has a similar effect, as does European funding in whatever context. 
TABLE 1 Synthesis of the three case studies

\begin{tabular}{|c|c|c|c|c|c|}
\hline & Example & Institutional context & Organization & Employment status & $\begin{array}{l}\text { Definition of working } \\
\text { practices }\end{array}$ \\
\hline $\mathrm{A}$ & $\begin{array}{l}\text { Rural sector in France } \\
1970 \text { s }\end{array}$ & $\begin{array}{l}\text { Centralization, rural } \\
\text { municipalities highly } \\
\text { dependent on the state } \\
\text { for expertise. }\end{array}$ & $\begin{array}{l}\text { State administration, } \\
\text { informal arrangements } \\
\text { based on pays }\end{array}$ & State contract officers & $\begin{array}{l}\text { Innovation: invention of } \\
\text { the action modalities of } \\
\text { the policy } \\
\text { Imposition of the new } \\
\text { model to rural elected } \\
\text { officials }\end{array}$ \\
\hline B & $\begin{array}{l}\text { Rural sector in France } \\
1980 \mathrm{~s}\end{array}$ & $\begin{array}{l}\text { Decentralization without } \\
\text { intercommunal bodies } \\
\text { Subsidies from multiple } \\
\text { sources }\end{array}$ & $\begin{array}{l}\text { Development } \\
\text { associations created by } \\
\text { elected officials and } \\
\text { financed by diverse } \\
\text { subsidies from higher } \\
\text { level bodies }\end{array}$ & $\begin{array}{l}\text { Semi-independent } \\
\text { officers 'creating their } \\
\text { own jobs' by capturing } \\
\text { subsidies } \\
\text { Very precarious } \\
\text { employment status. }\end{array}$ & $\begin{array}{l}\text { High autonomy. Small } \\
\text { role differentiation } \\
\text { between elected officials } \\
\text { and development officers }\end{array}$ \\
\hline $\mathrm{C}$ & $\begin{array}{l}\text { Rural sector in France } \\
2000^{\prime}\end{array}$ & $\begin{array}{l}\text { Decentralisation } \\
\text { Widespread application } \\
\text { of intercommmunal } \\
\text { bodies, including pays }\end{array}$ & $\begin{array}{l}\text { Formally constituted } \\
\text { inter-communal bodies } \\
\text { and pays }\end{array}$ & $\begin{array}{l}\text { Municipal contract } \\
\text { officers employed by } \\
\text { local authorities or } \\
\text { territorial civil servants }\end{array}$ & $\begin{array}{l}\text { Tension between well- } \\
\text { delineated management } \\
\text { logic and more } \\
\text { autonomous } \\
\text { development or } \\
\text { organizational practices }\end{array}$ \\
\hline D & $\begin{array}{l}\text { Social sector in towns, in } \\
\text { France } 1980 \mathrm{~s}\end{array}$ & $\begin{array}{l}\text { National policy } \\
\text { contracted at local level }\end{array}$ & $\begin{array}{l}\text { Suitable bodies } \\
\text { (consultants, association, } \\
\text { ) co-financed by the state } \\
\text { and local government }\end{array}$ & $\begin{array}{l}\text { Contract workers } \\
\text { cofinanced by the state } \\
\text { and the town halls }\end{array}$ & $\begin{array}{l}\text { Innovation: invention of } \\
\text { the action modalities of } \\
\text { the policy }\end{array}$ \\
\hline $\mathrm{E}$ & $\begin{array}{l}\text { Social sector in towns, in } \\
\text { France } 2000-9\end{array}$ & $\begin{array}{l}\text { Emergence of the } \\
\text { intercommunal level } \\
\text { Direct interventions } \\
\text { maintained by the state }\end{array}$ & $\begin{array}{l}\text { Integration of the teams } \\
\text { into the local authority } \\
\text { but numerous examples } \\
\text { of organizational } \\
\text { ambiguity }\end{array}$ & $\begin{array}{l}\text { Contract officers of local } \\
\text { communities } \\
\text { Territorial civil servants }\end{array}$ & $\begin{array}{l}\text { Procedures are stabilized } \\
\text { or bureaucratized } \\
\text { Forms of autonomy } \\
\text { preserved in } \\
\text { neighbourhood } \\
\text { management }\end{array}$ \\
\hline $\mathrm{F}$ & $\begin{array}{l}\text { Social sector in towns, in } \\
\text { England } 2000-9\end{array}$ & $\begin{array}{l}\text { Multiple sources of } \\
\text { finance. }\end{array}$ & $\begin{array}{l}\text { Suitable organizations } \\
\text { bound to a project } \\
\text { Outsourcing to the } \\
\text { voluntary sector } \\
\text { Partial mainstreaming. } \\
\text { Transversal partnerships }\end{array}$ & $\begin{array}{l}\text { Working arrangement } \\
\text { that facilitate } \\
\text { redeployment as } \\
\text { necessary }\end{array}$ & $\begin{array}{l}\text { Forms of autonomy } \\
\text { preserved in the } \\
\text { neighbourhood } \\
\text { management }\end{array}$ \\
\hline
\end{tabular}

Note: Row D has been established on the basis of the bibliography presented in the introduction.

The resulting uncertainties are unlikely to go without a response from local institutional actors. It is possible to see, in the case studies, different strategies to define a clearer administrative framework, either through the creation of an informal partnership or through 
integrating professional activities into the routine of local organizations. Each approach has its advantages and limitations. In the former, the informal approach, the broader uncertainties tend to reoccur within the partnership arrangements. A pays within the framework of the rural development in France in the 1980s (row B), an urban policy service in an inter-communal agency in France in the period after 2000 (row E) or a Local Strategic Partnership in an English district (row F) are very different entities. However, they share the same task of bringing multiple actors together, the same ambiguities of institutional accountability for practitioners and the same difficulty in determining a manoeuvring space for those involved in boundary spanning.

In the latter, the strategy of full integration, a more qualified judgement is possible. Compared to the preceding arrangements, attempts to integrate cross-cutting work- as represented in rural France since 2000 by the creation of intercommunal agencies (row C), by the attempts also in France to create a municipal service for neighbourhood management (row E) or by the desire of English local authorities to mainstream neighbourhood management (row F)- show a greater potential to normalize fuzzy jobs. In particular, when municipalities can derive resources from their own tax system or from unconditional transfers such as global grants as was the practice in France after decentralization, they may better integrate partnership activities within their organization. However, in all cases, normalization appears incomplete and fragile.

The occurrence of fuzzy jobs in different contexts implies, in turn, a reconsideration and rejection of the thesis of Donzelot and Roman (1994) that the figure of the chef de projet is merely a result of the reorganization of social work responsibilities. In any case, similar characteristics have been noted in a variety of recent French studies, irrespective of whether they use the term 'fuzzy jobs' - for example, regional policies for innovation (Crespy 2007), local training and employment (Cattla 2007; Mériaux and Verdier 2009), municipal transport 
policies (Purenne 2003) and the management of industrial risks (Gralepois 2008). Taking all this into account, one can conclude that fuzzy jobs are a product of cross-cutting problems, as suggested by (Duran and Thoenig 1996) and equally of complex wicked problems as conceptualized in the Anglo-American literature.

Organizational ambiguity and the question of job security In many ways, fuzzy jobs imply job insecurity. In the case of the development associations operating in rural France in the 1980s (row B of table 1), insecurity arose directly from the absence of long term funding for agencies created to receive subsidies. The same issue has arisen in England in programmes such as the New Deal for Communities where funding is of a fixed duration (row F). In the other cases, the link is less direct in the sense that permanent agencies are able to use staff with permanent contracts for the new tasks.

Nevertheless a tendency exists in both countries for established professionals to avoid the new work. For example, even though professional engineers from prestigious state ministries initiated policies for rural development in France, they recruited contract officers to undertake implementation (row A). Similarly, in England, professional town planners have tended to remain detached from the least clearly defined posts most of which are occupied by officers with looser professional qualifications (row F). The situation in relation to contemporary urban policy and rural development in France is less clear-cut. It appears, however, that established officers generally confine their work to activities that avoid direct contact with the population.

The reluctance of the established professions to become involved has, moreover, not as yet led in either country to the emergence of a new professional association for partnership or urban regeneration work. It is as though the empty space of partnership work has not been worth the attempt to control access to jobs. Alternatively, following the observations of Abbott (1981) in relation to high status professions, the hybrid character of the work has failed to 
appeal to notions of professional purity. In France, associations like the Plateforme du développement for rural areas and the Interréseau du développement social urbain for urban areas act more as exchange networks than as professional bodies. In France, an analogy can be drawn between partnership working and mediation, as analysed by Barthelemy (2009). Practitioners have sought to stabilize their work, not through belonging to a qualifying profession but instead through adopting a continuum of roles that vary from the 'emergent' to the 'established' (Demazière 2008) and that might cope with the conflicting demands of their specific organization. In Britain, the qualifying profession has persisted as an influential model for local government (Laffin and Entwistle 2000). The British Urban Regeneration Association has, for example, promoted itself as 'the leading membership organization championing regeneration' (a quotation taken from their web site (http://www.bura.org.uk/), accessed in December 2009). In addition, the Homes and Communities Academy (formerly known as the Sustainable Communities Academy) has promoted specialist undergraduate degrees with the long term aim of creating a new type of professional knowledge (see also http://www.hcaacademy.co.uk/courses/foundation-degree). It remains to be seen, however, whether the employers will prefer specialist graduates or postgraduates or good generalist candidates.

Job insecurity was an issue where attitudes varied markedly between those interviewed in France and England. The respondents in England were more confident about their prospects for career advancement and their ability to find new work in the future. Many took the view that, subject to the overall economic context, they possessed a degree of adaptability and flexibly that would enable them to work in a variety of different policy and business areas.

Professional autonomy: the sign of a new link between work and public action The most striking aspect of the case study examples is the open character of the fuzzy job 
descriptions, the high degree of autonomy enjoyed by those who occupy the relevant posts and the resulting potential for innovation and creativity. A degree of flexibility and discretion is common in job descriptions, as has been noted in sociological studies of the workplace and in ergonomics (Danielou et al. 1983). Some margin of manoeuvre is generally necessary for employees to undertake the work effectively. In the case of fuzzy jobs, the margin goes beyond a simple adjustment. Public action appears to be defined through the process of implementation and through the work of officials who seek to resolve problems that resist a prior analysis and diagnosis (Moisdon 1994).

Put slightly differently, public action in fuzzy jobs is above all about the ability of individuals to take the initiative, to cooperate with others and to take responsibility. It is about individual competences rather than qualifications as a basis for employment within an organization (Paradeise and Lichtenberger 2001). It is similar to the observations of Casey and Allen (2004) in relation to housing management in Britain, in being about professionalism in the workplace but not about professional work in the sense of enabling the application of a specific technical body of knowledge. Equally, it is not public sector bureaucratic work of the type that limits professional independence through a hierarchical chain of command. It is a distinctive and in some ways new type of public sector work. Such action corresponds broadly to the proposal of Friedson (2001) of professionalism as an alternative to both the bureaucracy and the market as a means of providing services, but in the absence of a professional association and in way that, partly for this reason, is very variable in its organizational context and also potentially unstable.

\section{CONCLUSIONS}

In local partnerships, the complexity of tasks and the very general character of aims push, to the 
point of crisis, the problems of organizational overlap or ambiguity noted in the English language literature (Landau 1969; Lerner and Wanat 1983). As is evidenced in the case studies, local partnership working has led to new means of coordination in France and England, involving relatively autonomous employees, as if this was a necessary precondition for successful policy implementation and the adaptation of measures to the realities of a local population (Bardach 1998; Williams 2002). Such co-ordination is often associated with grant funded projects that are limited in time and space. This characteristic, together with a lack of clearly defined technical expertise, means that partnership work does not easily conform to the classical model of professionalization, for example as outlined by Larson (1977) and Abbott (1995). It also means that the positions are relatively unattractive to those who possess the most solid and widely recognized qualifications and experience.

The question of boundary spanning in local partnerships is therefore not only about functional skills (Williams 2002; Sullivan et al. 2006). It is about a distinct type of work, a 'fuzzy' job, that reveals a recurrent association between three elements: the work content (the relative autonomy of the employer), the form of the organizational setting (ambiguity and overlap of responsibilities) and finally the working conditions (insecurity of employment). A fuzzy job is a concept, but it also refers to a real configuration of characteristics. Following the broad principles of grounded theory, it offers a hypothesis that can be applied to any context with similar characteristics and where, in particular, public policy requires flexibility and autonomous working at a local level (Jeannot 2008).

The emergence of a fuzzy job may, in part, be considered as a transient apprenticeship or as some type of organizational disorder associated with the early stages of a partnership, according to one's viewpoint. As responsibilities become clarified over time, as administrative procedures are simplified and as the sources of public funds become stabilized or absorbed into other programmes, the full characteristics of a fuzzy job may disappear. On the other hand, 
limits exist to the extent to which local authorities and other similar agencies can eliminate this type of work. New organizational ambiguities are likely to emerge, corresponding to new policy agendas (for example, sustainable development, local employment policy, health and community safety) and new targeted financing schemes. The phenomenon of fuzzy jobs is therefore simultaneously unstable for a specific policy intervention and stable in the way that it is likely to arise for successive examples of cross-cutting interventions, tied to new themes.

\section{ACKNOWLEDGMENTS}

This Anglo-French investigation was made possible by a grant from the Délégation Interministérielle à la Ville and the investigation on the rural development by a grant from the National Centre for Scientific Research (Action concertée incitative on 'work') and the Centre national de la fonction publique. Acknowledgements are also due to Vanessa Girard who undertook some of the interviews in the case study of four towns in France and to Paul Hickman for his understanding of neighbourhood management.

\section{REFERENCES}

Abbott, A. 1981. 'Status and Status Strain in the Professions', The American Journal of Sociology, 86, 4, 819-35.

Abbott, A. 1995. 'Boundaries of Social Work or Social Work of Boundaries? The Social Service Review Lecture', The Social Service Review, 69, 4, 545-62.

Andersen, H.T. and R. Van Kempen. 2003. 'New Trends in urban Policies in Europe: Evidence from the Netherlands and Denmark', Cities, 20, 2, 77-86.

Bailey, N. 2005. 'The Great Skills Debate: Defining and Delivering the Skills Required for Community Regeneration in England', Planning, Practice \& Research, 20, 3, 341-52.

Bardach, E. 1998. Getting Agencies to Work Together. The Practice and Theory of Managerial 
Craftsmanship. Washington, DC: Brookings Institution.

Barthélémy, F. 2009. 'Médiateur social, une profession émergente?', Revue française de sociologie, 50, 2, 287-314.

Béhar, D. and P. Estèbe 1996. 'Le chef de projet et le sous-préfet à la ville: entre norme et projet', Espaces et Sociétés, 84-85, 37-43.

Blanc, M. and J.-F. Sipp 2000. Etude sur les métiers de la ville et du développement social urbain, Rapport pour la Délégation Interministérielle à la Ville. Nancy, Universités Henri Poincaré, Nancy I \& Nancy II.

Bogdanor, V. 2005. Joined-up Government. Oxford: Oxford University Press.

Bourdieu, P. 1991. 'Une mission impossible. Entretien avec Pascale Raymond, chef de projet dans le Nord de la France', Actes de la recherche en sciences sociales, 90, 1, 84-94.

Brévan, C. and P. Picard. 2000. Une nouvelle ambition pour les villes: De nouvelles frontières pour les metiers. Paris: Délégation Interministérielle à la Ville.

Casey, R. and C. Allen. 2004. 'Social Housing Managers and the Performance Ethos: Towards a "Professional Project of the Self", Work Employment Society, 18, 2, 395-412.

Cattla, M. 2007. Le travail public régional. Toulouse: Octares.

Chevalier, G. 1996. 'Volontarisme et rationalité d'Etat. La politique de la ville', Revue française de sociologie, 37, 2, 209-35.

Chun, Y.H. and G.H. Rainey. 2005., 'Goal Ambiguity in US Federal Agencies', Journal of Public Administration Research and Theory, 15, 1, 1-30.

Clarke, M. and J. Stewart. 1997., Handling the Wicked Issues a Challenge for Government. Birmingham: University of Birmingham.

Cousin, O. 1996. 'Les mutations du travail social: de la transformation du public aux changements dans les modes de prise en charge', Sociologie du Travail 96, 2, 141-61.

Crespy, C. 2008. 'Mobilisation d'expertise et production du territoire regional', Les Annales de 
la recherche urbaine, 104, 1, 49-57.

Danielou, F., A. Laville and C. Teiger. 1983. 'Fiction et réalité du travail ouvrier', Cahiers français, 209, 1, 39-45.

Day, R. and J.V. Day. 1977. 'A Review of the Current State of Negotiated Order Theory: An Appreciation and a Critique', The Sociological Quarterly, 18, 1, 126-42.

De Maillard, J. 2004. Réformer l'action publique, la politique de la ville et les banlieues. Paris: LGDJ.

Demazière, D. 2008. 'L'ancien, l'établi, l'émergent et le nouveau, quelle dynamique des activités professionnelles?', Formation emploi, 101, 1, 41-54.

Donzelot, J. and P. Estèbe. 1994. L'état animateur. Essai sur la politique de la ville. Paris: Editions Esprit.

Donzelot, J. and J. Roman. 1998. 'Les nouvelles donnes du social', Esprit, 3-4, 1, 7-25.

Douillet A. C., J. De Maillard 2008. 'Le magistrat, le maire et la sécurité publique, action publique partenariale et dynamiques professionnelles', Revue française de sociologie, 49, 793-818.

Duran, P. and J.C. Thoenig. 1996. 'L'État et la gestion publique territoriale', Revue française de science politique, 46, 4, 580-623.

Epstein R. 2005. 'Gouverner à distance. Quand l'Etat se retire des territoires', Esprit, 319, 96111. (no volume number)

Etzioni, A. 1969. The Semi-Professions and Their Organization: Teachers, Nurses, Social Workers. New York: The Free Press.

Freidson, E. 2001. Professionalism: The Third Logic. London: Polity Press.

Friend, J.K., J.M. Power and C.J.L. Yewlett. 1974. Public Planning. London: Routledge.

Gaudin, J.P. 1999. Gouverner par contrat: L'action publique en question. Paris: Presses de Sciences Po. 
Glaser, B.C and A. Strauss. 1967. The Discovery of Grounded Theory: Strategies for Qualitative Research. Chicago, IL: Aldine.

Gralepois, M. 2008. Les risques collectifs dans les agglomérations françaises. Thèse de sociologie, Université Paris-Est.

Hall, S. and P. Hickman. 2002. 'Neighbourhood Renewal and Urban Policy: A Comparison of New Approaches in England and France', Regional Studies, 36, 6, 691-96

Harrison, T. 2000. 'Urban Policy: Addressing Wicked Problems', in H. Davies, S.M. Nutley and P.C. Smith (eds), What Works?: Evidence-Based Policy and Practice in Public Services. Bristol: Policy Press.

Ion, J. 1996. Le travail social à l'épreuve du territoire. Paris: Dunod.

Jacquier, C. 2005. 'On Relationships between Integrated Policies for Sustainable Urban Development and Urban Governance', Tijdschrift voor economische en sociale geografie, $96,4,363-76$.

Jeannot, G. 2005a. 'Les métiers flous du développement rural', Sociologie du Travail, 47, 1, $17-35$.

Jeannot, G. 2005b. Les métiers flous, travail et action publique. Toulouse: Octares.

Jeannot, G. 2008. 'Les fonctionnaires travaillent-ils de plus en plus? Un double inventaire des recherches sur l'activité des agents publics', Revue française de science politique, 58, 1, $123-40$.

Kagan, C. 20007. 'Interpersonal Skills and Reflection in Regeneration Practice', Public Money \& Management, 27, 3, 169-74.

Laffin, M. and T. Entwistle. 2000. 'New problems, Old Professions? The Changing National World of Local Government Professions', Policy and Politics, 28, 2, 207-20.

Landau, M. 1969. 'Rationality and the Problem of Duplication and Overlap', Public Administration Review, 29, 4, 346-58. 
Larson, M.S. 1977. The Rise of Professionalism. Berkeley, CA: University of California Press.

Le Galès, P. 1995. 'Politique de la ville en France et Grande Bretagne, volontarisme et ambiguïté de 1'Etat', Sociologie du Travail, 37, 22, 249-75.

Le Galès, P and J. Mawson. 1994. Management Innovations in Urban Policy: Lessons from France. Luton: Local Government Management Board.

Lerner, A.W. and J. Wanat. 1983. 'Fuziness and Bureaucracy', Public Administration Review, $43,6,500-9$.

Lewis, D. 2008. 'Using Life Histories in Social Policy Research: The Case of Third Sector/Public Sector Boundary Crossing', Journal of Social Policy, 37, 4, 559-78.

Ling T. 2002. 'Delivering joined-up government in UK : dimensions, issues and problems, Public Administration, 80, 4, 615-642.

Lowndes, V and C. Skelcher. 1998. 'The Dynamic of Multi-organizational Partnerships: An Analysis of Changing Modes of Governance', Public Administration, 76, 2, 313-33.

March, J.G. and J.P. Olsen. 1976. Ambiguity and Choice in Organizations. Oslo: Univesitet Sforlaget.

Mériaux, O. and E. Verdier. 2009. 'Gouvernances territoriales et émergence d'une politique du rapport salarial', Espaces et sociétés, 136-7, 1, 17-31.

Mjøset, L. 2005. 'Can Grounded Theory Solve the Problems of its Critics?', Sosiologisk tidsskrift, 13, 4, 379-408.

Moisdon, J.C. 1994. 'Appareils gestionnaires et travail ou de la lacune comme opportunité', Sociologie du travail, Hors série, 1-19.

Newman, J. 2001. Modern Governance: New Labour, Policy and Society. London: Sage.

ODPM - Office of the Deputy Prime Minister (collective author). 2004. Skills for Sustainable

Communities. The Egan Review. London: ODPM.

Paradeise, C and Y. Lichtenberger. 2001. 'Compétence, compétences', Sociologie du travail, 
$43,1,33-48$.

Péraldi, M., 1996. 'La cité militante', Espaces et sociétés, 84-85, 1, 23-36.

Pollitt, C. 2003. 'Joined-up Government: A Survey', Political Studies Review, 1, 1, 34-49.

Profession Banlieue (collective author). 1993. La place du chef de projet et de son équipe dans la mise en oeuvre du contrat de ville. Saint-Denis: Profession Banlieue.

Profession Banlieue (collective author). 1999. Entre procédure et politique. Les chefs de projet en Seine-Saint-Denis. Saint-Denis: Profession Banlieue.

Purenne, A. 2003. L'action publique par le bas, les transports urbains de la communauté urbaine de Lyon. Thèse de sociologie ENTPE.Rives.

Rittel, H.W.J. and M.M. Webber. 1973. 'Dilemmas in a General Theory of Planning', Policy Sciences, 4, 2, 155-69.

Rizzo, J.R., R.J. House and S. I. Lirtzman. 1970. 'Role Conflict and Ambiguity in Complex Organizations', Administrative Science Quarterly, 15, 3, 150-63.

Stébé, J.-M. 2005. La médiation dans les banlieues sensibles. Paris: Presses universitaires de France.

Stewart, M. and J. Howard. 2004. Mainstreaming in NDC Areas: Evidence from the National Evaluation 2003/04, Research Report 25. Sheffield: Sheffield Hallam University.

Strauss, A. 1982. 'Interorganizational Negotiation', Journal of Contemporary Ethnography, 11, $3,350-67$.

Strauss, A. 1988. 'The Articulation of Project Work: an Organizational Process', The Sociological Quarterly, 29, 2, 163-78.

Strauss, A., S. Fagerhaugh, B. Suczek and C. Wiener. 1985. Social Organization of Medical Work. Chicago, IL: University of Chicago Press.

Strauss, A., L. Schatzman, R. Bucher, D. Ehrlich and M. Sabshin. 1963. 'The Hospital Audits Negotiated Order', in E. Freidson (ed.), The Hospital in Modern Society. New York: The 
Free Press, pp. 147-68.

Sullivan, H., M. Barnes and E. Matka. 2006. 'Collaborative Capacity and Strategies in Areabased Initiatives', Public Administration, 84, 2, 289-310.

Sullivan, H. and C. Sklecher. 2002. Working across Boundaries. London: Palgrave.

Thoenig, J.C. 1994. 'La gestion systémique de la sécurité publique', Revue française de sociologie, 35, 3, 357-92.

Wilensky, H.L. 1964. 'The Professionalization or Everyone?', The American Journal of Sociology, LXX, 2, 137-58.

Williams, P. 2002. 'The Competent Boundary Spanner', Public Administration, 80, 1, 103-24.

Date received 12 July 2009. Date accepted 18 June 2010. 